\title{
Assessment of thyroid status in pregnant women and in patients taking oral contraceptives by a free thyroxine index
}

\author{
T. M. D. GimLETTE AND A. Piffanelli \\ From the Liverpool Clinic, Myrtle Street, Liverpool
}

SYNOPSIS The results of using a product of serum thyroxine and triiodothyronine binding coefficient, estimated by simple methods, to give a 'free thyroxine index' in normal women, in pregnant women, and in patients taking oral contraceptives is described. The method is believed to provide a reliable means of assessing thyroid status, and very close agreement, with no significant difference between the mean values obtained for the free thyroxine index, was found in the groups studied. Certain changes, which may be significant, in the values obtained in patients on oral contraceptive treatment of varying duration were noted.

In pregnancy it has been recognized that physiological changes lead to difficulty in the establishment of thyroid status; it is desirable to avoid radioiodine studies in vivo and interest has therefore been directed to methods in vitro. However, it was shown that total thyroid hormone in the plasma, measured chemically as protein-bound iodine (PBI), was raised in pregnancy (Heinemann, Johnson, and Mann, 1948) and subsequently that this was associated with a physiological increase in thyroxine-binding globulin (TBG) (Dowling, Freinkel, and Ingbar, 1956a). Similar changes were shown to be produced by the administration of oestrogen to normal subjects (Dowling, Freinkel, and Ingbar, 1956b), and by oestrogen-containing oral contraceptives (Hollander, Garcia, Sturgis, and Selenkow, 1963; Larsson-Cohn, 1965). Conversely, a measurement of the proportion of free thyroid hormone in plasma showed that pregnancy was associated with decreased values (Hamolsky, Golodetz, and Freedberg, 1959). Such tests, directly or indirectly giving a measure of the free fraction of thyroid hormone, help to provide a more precise index of thyroid status because, if the value obtained is multiplied by total thyroid hormone, the product is believed to represent the concentration of free hormone, which is believed to determine thyroid status (Robbins and Rall, 1960; Sterling and Brenner, 1966).

Total thyroid hormone may be estimated chemically as PBI, or as thyroxine by saturation analysis using radioiodine labelled thyroxine (Murphy, 1965). Received for publication 11 April 1968.
The free fraction may be estimated directly by relatively exacting techniques of equilibrium dialysis (Sterling and Hegedus, 1962; Oppenheimer, Squef, Surks, and Hauer, 1963) or Sephadex column separation (Lee, Henry, and Golub, 1964). Simpler methods are provided by a group of techniques in which the proportion of free hormone is indicated by the fraction of an aliquot of radioiodine-labelled triiodothyronine (T3) added to the test serum which is bound to protein; the unbound T3 can be separated by adsorption to erythrocytes (Hamolsky et al, 1959), or to ion-exchange resins, charcoal, or Sephadex (Herbert, Gottlieb, Lau, Gilbert, and Silver, 1965; Gimlette, 1967).

In the present study simple methods are used to estimate total thyroxine, and the free fraction and the product, expressed as 'free thyroxine index' (Clark and Horn, 1965), is compared in normal subjects, in pregnant women, and in patients taking oral contraceptives.

\section{METHODS AND MATERIAL}

SERUM THYROXINE This was estimated by saturation analysis according to Murphy (1965).

TRIIODOTHYRONINE BINDING COEFFICIENT ${ }^{1}$ (T3BC) This was estimated by the method of Gimlette (1967) using Sephadex. The results in this study are expressed as the percentage of that obtained using pooled normal serum examined with each batch of test sera.

${ }^{1}$ Otherwise known as $T_{\mathbf{2}}$-uptake test. 
Serum thyroxine $(\mu \mathrm{g} / 100 \mathrm{ml})$ and T3BC (\%) were multiplied to give a 'free thyroxine index'.

PATIENTS Three groups of patients were studied.

Normal controls These were 92 women aged 15 to 50 who were euthyroid, without overt thyroid disease, and taking no medication.

Pregnant These were 36 patients in the second and third trimesters of pregnancy.

Patients on oral contraceptives One hundred and seven patients who had been taking a number of different combined oestrogen-progestogen preparations for varying times, but not less than two months, were chosen. No special note was made of the time in the cycle when samples were obtained; earlier work had shown that this made no significant difference (Hollander et al, 1963; Goolden, Gartside, and Sanderson, 1967).

The following oral contraceptives were studied (numbers of patients taking each in parenthesis):

\begin{tabular}{lll} 
Proprietary Name & $\begin{array}{l}\text { Composition of } \\
\text { Contraceptive }\end{array}$ & Dose \\
\hline Gynovlar (54) & Norethindione & $3 \mathrm{mg}$ \\
& Ethinyl-oestradiol & $0.05 \mathrm{mg}$ \\
Lyndiol (18) & Lynoestrol & $5 \mathrm{mg}$ \\
Yolidan (9) & Mestranol & $0.1 \mathrm{mg}$ \\
& Megestrol acetate & $4 \mathrm{mg}$ \\
Anovlar (4) & Mestranol & $0.1 \mathrm{mg}$ \\
Orthonovin (11) & Norethindione & $4 \mathrm{mg}$ \\
Ovulen (8) & Ethinyl-oestradiol & $0.05 \mathrm{mg}$ \\
& Norethindione & $2 \mathrm{mg}$ \\
Conovid (3) & Mestranol & $0.1 \mathrm{mg}$ \\
& Ethindiol diacetate & $1 \mathrm{mg}$ \\
& Mestranol & $\mathbf{0 . 1} \mathrm{mg}$ \\
& Norethynodrel & $5 \mathrm{mg}$ \\
& Mestranol & $0.075 \mathrm{mg}$
\end{tabular}

RESULTS

The results are shown in Figs. 1 and 2 and in Tables I and II. The values given are the mean \pm 1 SD.

SERUM THYROXINE The mean level was significantly raised in both pregnant and oral contraceptive patients $(P<0.001)$, but there was no significant difference between these two groups $(P>0.05)$. Of the individual contraceptives, only Anovlar showed a significant difference from the mean of the group (P $<0.02)$.

T3 BINDING COEFFICIENT The mean level was significantly lower in both pregnant and oral contraceptive patients than in the controls $(P<0.001)$, and there was a doubtfully significant difference between pregnant and patients taking oral contraceptives $(P<0.05,>0.02)$. There was no significant difference between any of the individual contraceptives and the rest of the group.

FREE THYROXINE INDEX There was no significant difference between normal controls and either pregnant or oral contraceptive groups, or between any

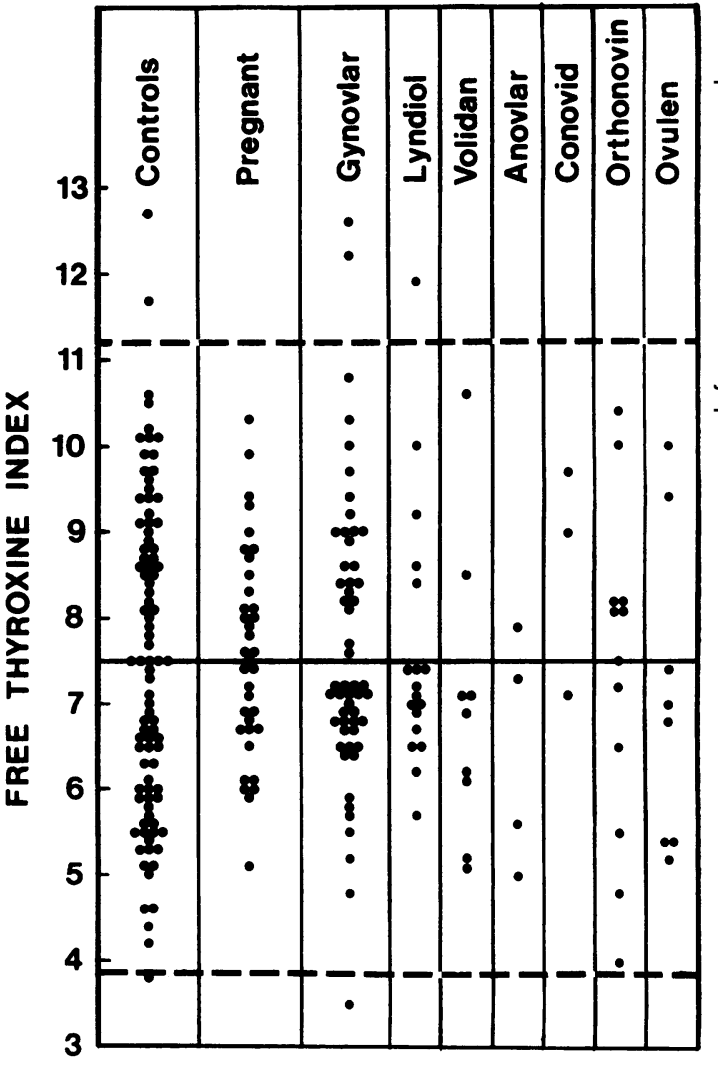

FIG. 1. Free thyroxine index in normal controls, in pregnant women, and during oral contraceptive treatment The mean of the normal controls is indicated by the horizontal lines and normal limits $( \pm 2 S D s)$ by the broken lines.

of the individual oral contraceptives groups. The effect of duration of treatment with oral contracep-o tives was tested by dividing the patients into three groups as shown in Table II.

SERUM THYROXINE There was a significant difference between groups $B$ and $C(P<0.001)$ and between groups $A$ and $B$ combined and $C(P<0.01)$, but not between groups $\mathbf{A}$ and $\mathbf{C}$ or $\mathbf{A}$ and $\mathbf{B}$.

T3 BINDING COEFFICIENT There was no significant difference $(P>0.05)$ between any of the groups.

FREE THYROXINE INDEX There was a significant $t^{+}$ difference between groups $B$ and $C$, and between groups $A$ and $B$ combined and $C(P<0.05)$, but not between groups $A$ and $C$.

The difference between group $\mathrm{C}$ and the normal $\mathbb{Q}_{2}$ controls was not significant ( $P>0.05)$. 
FIG. 2. Triiodothyronine binding coefficient and serum thyroxine. The normal range $( \pm 2 S D s)$ of each is indicated

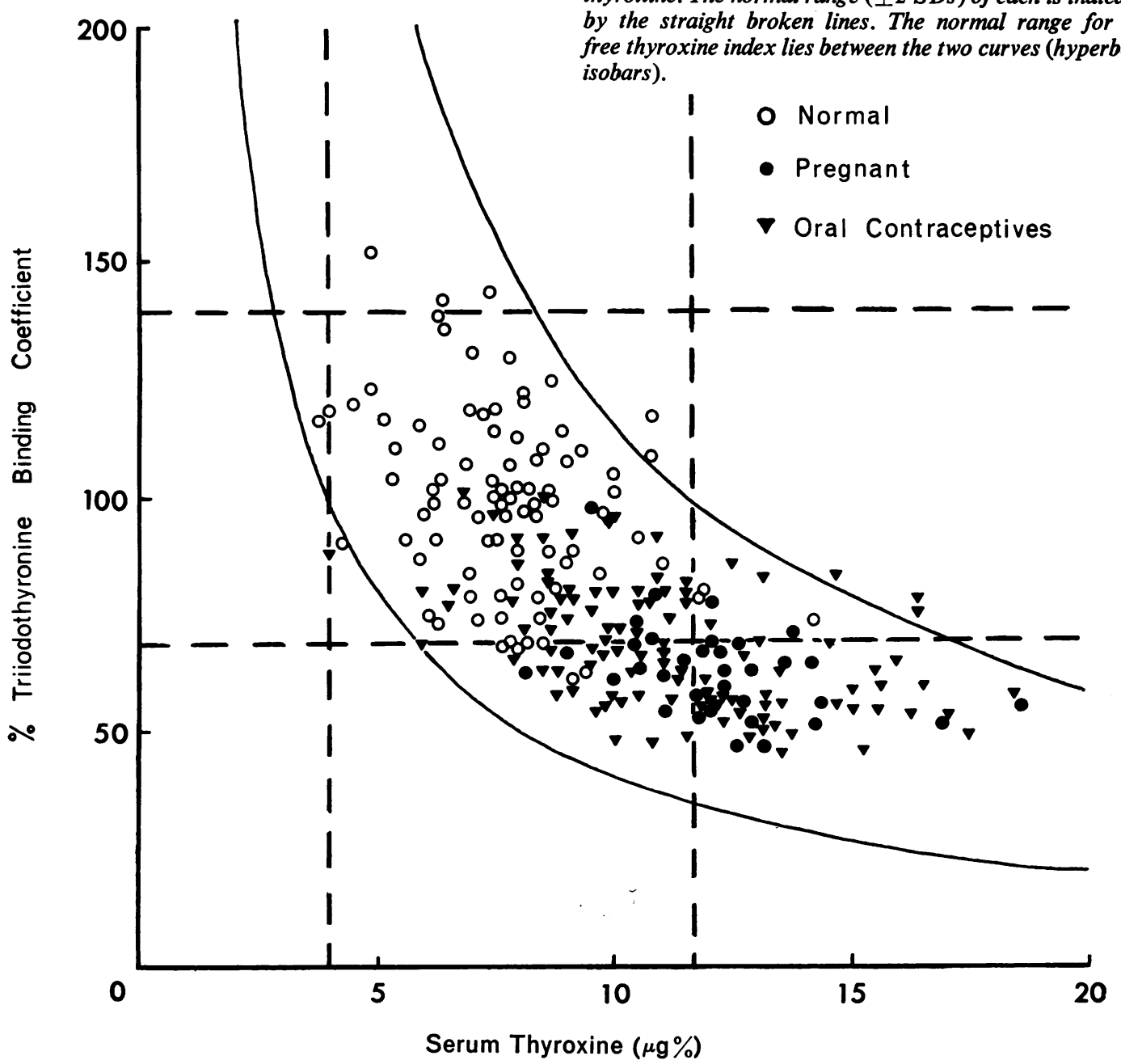

TABLE I

SERUM THYROXINE, T3 BINDING COEFFICIENT, AND 'FREE THYROXINE INDEX'1

TABLE II

\begin{tabular}{|c|c|c|c|}
\hline Patients & $\begin{array}{l}\text { Serum } \\
\text { Thyroxine } \\
(\mu g \%)\end{array}$ & $\begin{array}{l}\text { T3 Binding } \\
\text { Coefficient } \\
(\%)\end{array}$ & $\begin{array}{l}\text { 'Free T4 } \\
\text { Index' }\end{array}$ \\
\hline $\begin{array}{l}\text { Normal controls (92) } \\
\text { Pregnant women (36) } \\
\text { Oral contraceptives (107 } \\
\text { Gynovlar (54) } \\
\text { Lyndiol (18) } \\
\text { Yolidan (9) } \\
\text { Anovlar (4) } \\
\text { Orthonovin (11) } \\
\text { Ovulen (8) } \\
\text { Conovid (3) }\end{array}$ & \begin{tabular}{r}
\multicolumn{1}{c}{$7.7 \pm 1.88$} \\
$12.04 \pm 2.08$ \\
$11.20 \pm 2.76$ \\
$11.21 \pm 2.82$ \\
$11.30 \pm 2.42$ \\
$11.14 \pm 2.68$ \\
$8.93 \pm 1.84$ \\
$11.24 \pm 3.07$ \\
$11.55 \pm 3.11$ \\
$12.33 \pm 4.38$
\end{tabular} & $\begin{array}{l}99 \cdot 1 \pm 18.5 \\
63 \cdot 7 \pm 10 \cdot 7 \\
68.6 \pm 12 \cdot 7 \\
69.9 \pm 12 \cdot 3 \\
67.9 \pm 12.9 \\
65 \cdot 1 \pm 13 \cdot 1 \\
72.5 \pm 7 \cdot 1 \\
66.8 \pm 11 \cdot 7 \\
62.5 \pm 8 \cdot 5 \\
75.7 \pm 21.3\end{array}$ & $\begin{array}{l}7.51 \pm 1.84 \\
7.59 \pm 1.19 \\
7.49 \pm 1.65 \\
7.67 \pm 1.68 \\
7.62 \pm 1.53 \\
7.00 \pm 1.83 \\
6.45 \pm 1.36 \\
7.19 \pm 1.79 \\
7.06 \pm 1.99 \\
8.53 \pm 1.23\end{array}$ \\
\hline
\end{tabular}

DURATION OF TREATMENT WITH ORAL CONTRACEPTIVES ${ }^{1}$

\begin{tabular}{llll}
$\begin{array}{l}\text { Duration of } \\
\text { Treatment }\end{array}$ & $\begin{array}{l}\text { Serum } \\
\text { Thyroxine } \\
(\mu \mathrm{g} \%)\end{array}$ & $\begin{array}{l}\text { T3 Binding } \\
\text { Coefficient } \\
(\%)\end{array}$ & $\begin{array}{l}\text { 'Free T4 } \\
\text { Index' }\end{array}$ \\
\hline $\begin{array}{c}\text { Group A (34) } \\
\text { 2-6 months }\end{array}$ & $11.05 \pm 2.97$ & $70.2 \pm 10.8$ & $7.58 \pm 2.12$ \\
$\begin{array}{c}\text { Group B (48) } \\
\text { 6-12 months }\end{array}$ & $11.99 \pm 2.80$ & $65.8 \pm 13.4$ & $7.71 \pm 1.41$ \\
$\begin{array}{c}\text { Group C (25) } \\
>12 \text { months }\end{array}$ & $9.93 \pm 1.96$ & $72.4 \pm 15.6$ & $6.94 \pm 1.30$ \\
\hline 12 man & & &
\end{tabular}

${ }^{1}$ Results are given as the mean $\pm 1 \mathrm{SD}$. Numbers of subjects in each group in brackets.

${ }^{1}$ Results are given as the mean \pm 1 SD. Numbers of subjects in each group in brackets. 
The distribution of duration of therapy amongst the various oral contraceptive preparations was uniform. When the group of 54 patients receiving Gynovlar was considered alone from this point of view the results were the same.

\section{DISCUSSION}

In a number of previous studies the results of combined estimation of total thyroxine (usually as PBI) and free thyroxine (by various methods) in normal subjects, in pregnant women, and in patients taking oral contraceptives have been compared. Using a simple free thyroxine index calculated from resin uptake of T3 and PBI, Clark and Horn (1965) found no significant difference in pregnancy although the mean value was lower. Oppenheimer et al (1963), using equilibrium dialysis, obtained values slightly, but not significantly, lower in pregnancy; using similar methods, Sterling and Hegedus (1962) and Sterling and Brenner (1966) found significantly lower values in pregnancy. Using a method of Sephadex column separation, Lee et al (1964) obtained normal values in pregnancy; with similar methods Wellby and O'Halloran (1966) obtained values lower, but not significantly, in subjects with increased thyroxine binding. Goolden et al (1967), using a free thyroxine index calculated from T3 resin uptakes, found values normal in pregnancy but significantly higher on an oral contraceptive. Hollander et al (1963), using the red cell uptake of T3, obtained lower values in patients taking oestrogen. Gimlette (1965), using a simple nonequilibrium dialysis technique, obtained normal values in pregnancy.

In these studies in general, raised values for total thyroxine and depressed values for the free fraction of thyroxine were obtained in pregnant women and in patients taking oestrogens. It has been recognized that either of these measurements alone tend to give misleading results, while in combination they give normal values in the great majority of patients. It is therefore desirable to have simple and reliable techniques for both types of measurement readily available.

The methods described in this study have certain advantages in the assessment of thyroid status in situations where thyroxine binding is abnormal. They are technically simple to carry out and suitable for routine use in smaller laboratories. The estimation of PBI is widely available and may be used satisfactorily instead of serum thyroxine in the great majority of cases. The estimation of the free fraction of thyroxine by the Sephadex method has the advantage of giving a spread of values in abnormal conditions similar to those obtained for the per- $\overrightarrow{\vec{D}}$ centage of free thyroxine by the more exactingo equilibrium dialysis techniques (Sterling and Hege-듬 dus, 1962; Sterling and Brenner, 1966; Oppenheimer et al, 1963). It is therefore probably more suitable $\mathbb{\otimes}$ for combination with serum thyroxine to obtain an absolute value for 'free thyroxine' than are certain ${ }^{\infty}$ other techniques which give a much smaller spread $\vec{O}$ of abnormal values (Herbert et al, 1965; Garnett, $\vec{\overrightarrow{ }}$ Pollard, and Webber, 1965). This suggestion is $\stackrel{\sigma}{\omega}$ supported by the normal values for the "free thyroxine $\overrightarrow{0}$ index' generally obtained in this study in euthyroid subjects with altered thyroxine binding in pregnancy and during oestrogen administration.

The changes noted in relation to duration of $\vec{\nu}$ treatment with oral contraceptives are of some 0

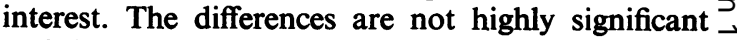
and they may be of no importance, but they suggest $z$ two possibilities: first, that there may be some decrease in thyroid function, and secondly that there may be some decrease in the effect of the drugs upon thyroxine binding after prolonged oral contraceptive treatment.

We wish to express our thanks to $\mathrm{Dr}$ B. M. Hibbard $\square$ and to the staff and patients of the Family Planning Association, Liverpool, for making available sera from pregnant patients and from patients taking oral contraceptives.

One of the authors, A.P., was the recipient of a Council of Europe medical fellowship no. 5143.

\section{REFERENCES}

Clark, F., and Horn, D. B. (1965). J. clin. Endocr., 25, 39.

Dowling, J. T., Frienkel, N., and Ingbar, S. H. (1956a). J. clin. Invest., 35, 1263.

Garnett (1956b). J. clin. Endocr., 16, 1491 318.

Gimlette, T. M. D. (1965). J. clin. Path., 18, 293.

(1967). Ibid., 20, 170.

Goolden, A. W. G., Gartside, J. M., and Sanderson, C. (1967). 음 Lancet, 1, 12.

Hamolsky, M. W., Golodetz, A., and Freedberg, A. S. (1959). J. clin. $\frac{D}{O}$ Endocr., 19, 103.

Heinemann, M., Johnson, C. E., and Mann, E. B. (1948). J. clin. Invest., 27, 91.

Herbert, V., Gottlieb, C. W., Lau, K. S., Gilbert, P., and Silver, S. (1965). J. Lab. clin. Med., 66, 814.

Hollander, C. S., Garcia, A. M., Sturgis, S. H., and Selenkow, H. A. N (1963). New Engl. J. Med., 269, 501.

Larsson-Cohn, U. (1965). Lancet, 1, 317.

Lee, N. D., Henry, R. J., and Golub, O. J. (1964). J. clin. Endocr., 24, 486.

Murphy, B. P. (1965). J. Lab. clin. Med., 66, 161.

Oppenheimer, J. H., Squef, R., Surks, M. I., and Hauer, H. (1963). \& J. clin. Invest., 42, 1769.

Robbins, J., and Rall, J. E. (1960). Physiol. Rev., 40, 415.

Sterling, K., and Hegedus, A. (1962). J. clin. Invest., 41, 1031.

- and Brenner, M. A. (1966). Ibid., 45, 153.

Wellby, M., and O'Halloran, M. W. (1966). Brit. med. J., 2, 668. 